\title{
Jati Diri Masyarakat Wewewa yang Termanifestasi pada Tuturan Lisan Oka: Kajian Etnopragmatik
}

\author{
Kanisius Kami ${ }^{1}$, R. Kunjana Rahardi ${ }^{2}$, Pranowo ${ }^{3}$ \\ ${ }^{1}$ Program Studi Pendidikan Bahasa Indonesia, Sekolah Tinggi Keguruan dan Ilmu Pendidikan Weetebula; \\ ${ }^{2-3}$ Program Magister Pendidikan Bahasa dan Sastra Indonesia, FKIP, Universitas Sanata Dharma Yogyakarta
}

\begin{abstract}
*Corresponding Author: Kanisius Kami, Program Studi Pendidikan Bahasa Indonesia, Sekolah Tinggi Keguruan dan Ilmu Pendidikan Weetebula, Email: romokanis77@yahoo.com
\end{abstract}

\begin{abstract}
Abstrak: Penelitian ini bertujuan mendeskripsikan jati diri masyarakat Wewewa, Sumba Barat Daya, NTT, yang termanifestasi dalam kearifan lokal pada tuturan lisan Oka. Penelitian ini tergolong penelitian kualitatif dengan pendekatan etnopragmatik. Artinya, untuk memahami jati diri masyarakat Wewewa, terikat konteks situasi dan konteks budaya. Konteks situasi bertujuan menggali apa yang terjadi, entitas yang terlibat dalam kegiatan tersebut, keadaan, di mana, dan kapan kegiatan itu terjadi. Sementara konteks budaya mengacu pada nilai yang dianut oleh masyarakat.Objek yang dikaji adalah gambaran jati diri masyarakat Wewewa yang tercermin dalam tuturan lisan $\mathrm{Oka}$. Sumber data primer adalah tuturan-tuturan lisan $O k a$. Sumber data primer ini diperoleh dari penutur yang menuturkan tradisi lisan $O k a$. Sumber data primer dijaring peneliti dari warga masyarakat Wewewa berdasarkan wawancara (percakapan etnografis). Sementara sumber data sekunder diperoleh peneliti dari dokumen-dokumen yang berkaitan langsung dengan tradisi lisan $O k a$. Instrumen penelitian ini adalah peneliti sendiri. Metode pengumpulan data penelitian ini adalah melalui observasi, wawancara, dan studi dokumentasi. Metode analisis data yakni padan ekstralingual yaitu metode analisis yang digunakan untuk menghubungkan masalah bahasa dengan hal yang berada di luar bahasa. Sementara teknik analisis data yaitu transkripsi data, penerjemahan gloss data, seleksi data, identifikasi data, klasifikasi data, dan menganalisis serta menginterpretasi data sehingga dapat dilaporkan pada bagian pembahasan data. Berdasarkan hasil penelitian, peneliti dapat menyimpulkan bahwa dalam tuturan tradisi lisan $O k a$, ditemukan jati diri masyarakat Wewewa yang termanifestasi dalam tuturan tradisi lisan $O k a$.
\end{abstract}

Kata Kunci: Tradisi Lisan, Kearifan Lokal, Jati Diri.

\section{Pendahuluan}

Karya misi Gereja bertemu dan bergaul dengan unsur-unsur di luar Gereja (agama lain, kebudayaan setempat dan situasi sosial kemasyarakatan) dan mengajak mereka untuk berziarah bersama menuju kepada Allah. Untuk maksud ini Gereja harus bersikap terbuka dengan situasi konkret yang ada di sekitarnya. Gereja sebagai himpunan orang beriman, tidak perlu menciptakan harapan-harapan misioner yang mustahil dapat tercapai, seperti kecenderungan untuk secara institusional mengkristenkan dunia.
Seperti dikatakan oleh Konsili bahwa Gereja tidak menolak ilai-nilai yang benar dan suci (GS 53, NA 2), begitu pula sebaliknya, Gereja di dalam karya misinya dengan cara yang tepat menawarkan nilai-nilai yang dihayatinya agar tidak ditolak oleh agama dan budaya setempat. Penolakan terhadap Gereja tidak pertama-tama berarti penolakan terhadap Allah, tetapi harus ditafsir sebagai ketidak berhasilan Gereja dalam

Indonesia memiliki kekayaan tradisi lisan yang tersebar di seluruh wilayah Nusantara (Danandjaja, 1997:9-12). Tradisi lisan sebagai kekayaan budaya bangsa merupakan salah satu bentuk ekspresi kebudayaan daerah yang berharga, 
sebab tidak hanya menyimpan nilai-nilai budaya dari masyarakat tradisional, tetapi juga dapat menjadi akar budaya dari suatu masyarakat baru. Keberadaan tradisi lisan patut mendapat perhatian, karena tradisi lisan memberi andil yang sangat besar bagi pembentukan jati diri bangsa, dan juga bagi proses regenerasi bangsa kita. Tradisi lisan sebagai kekayaan budaya daerah,seharusnya menjadi fundamen utama dalam pembentukan jati diri bangsa. Jati diri adalah karakteristik jiwa bangsa yang bersumber dari akar budaya masingmasing. Budaya-budaya daerah yang membentuk karakteristik masyarakatnya masing-masing, dengan sendirinya akan memberi jati diri pada setiap anak bangsa Indonesia. Dalam situasi apapun, jati diri bangsa harus tetap ada. Oleh karena itu, keberadaan budaya daerah tidak bisa diabaikan dalam kehidupan masyarakat. Dikatakan demikian, karena budaya lokal memiliki peranan (role) yang sangat pentingdalam kehidupan masyarakatnya. Budaya daerahpada dasarnya dipandang sebagai landasan bagi pembentukan jati diri bangsa (nation identity).William (1999:223) mengatakan bahwa budaya daerah dapat menentukan norma untuk perilaku yang teratur, serta kesenian verbal pada umumnya meneruskan kebiasaan dan nilai-nilai budaya daerah. Setiap bentuk budaya daerah dapat menambah eratnya ikatan solidaritas masyarakat yang bersangkutan. Bascom dalam Danandjaja (1997:19) mengemukakan, ada empat peranan budaya daerah yakni: (a) sebagai sistem proyeksi, yakni pencerminan angan-angan suatu kelompok;(b) sebagai pengesahan pranata dan lembaga kebudayaan;(c) sebagai alat pendidikan anak; dan (d) sebagai alat kontrol agar norma-norma masyarakat selalu dipatuhi anggota kelompoknya.

Masyarakat Wewewa memiliki banyak ritual sebagai bukti bahwa mereka senantiasa menjunjung tinggi tradisi kebudayaan yang diwariskan oleh leluhur. Masyarakat ini memiliki corak tradisi dan budaya yang khas, baik dalam dimensi wujud maupun isi. Kekhasan budaya masyarakat Wewewa dapat dilihat dalam berbagai tradisi lisan dan ritual warisan para leluhurnya. Salah satu tradisi lisan warisan leluhur yang hidup dan berkembang dalam realitas sosial budaya masyarakat Wewewa adalah $O k a$.

Secara harafiah, kata $\mathrm{Oka}$ dalam bahasa daerah berarti "berteriak dengan suara lantang atau nyaring".Dalam hubungandengan tradisi masyarakat sebagai sebuah ritual,Oka berarti tuturan lisan berbentuk tanya-jawab sesuai dengan konteks ritual diadakan. Pihak yang bertanya disebut tuwa dan pihak yang menjawab disebut wale. Proses ritual $\mathrm{Oka}$ tersebut sesungguhnya memiliki tiga bagian yaitu bagian pembuka, inti, dan penutup (Dairo, 2015: 20). Bagian pembuka adalah tuturan sapaan. Tetua adat mewakili pemilik rumah menyapa tetua adat yang mewakili rombongan atau tamu yang datang. Bagian inti adalah tuturan untuk menyelidiki dari kedua pihak, berkaitan dengan maksud atau tujuan rombongan atau tamu yang datang. Bagian penutup adalah tahap di mana tamu atau rombongan dipersilakan masuk ke kampung apabila dalam proses penyelidikan,tidak ditemukan halangan apapun. Artinya, tuan rumah menerima kehadiran tamu atau rombongan yang datang berkunjung. Dalam bagian penutup ini, pintu gerbang dapat dibuka dan tamu dipersilakan masuk.

Menurut kepercayaan masyarakat Wewewa, ritual $O k a$ tidak dapat dilaksanakan dalam setiap peristiwa upacara adat. Ritual $O \mathrm{ka}$ hanya dapat dilaksanakan dalam peristiwa atau upacara-upacara adat tertentu. Hal ini menunjukkan bahwa ritual $\mathrm{Oka}$ yang dilaksanakan dalam upacara adat masyarakat Wewewa memiliki fungsi, makna, serta tujuan tertentu. Adapun beberapa peristiwa atau upacara adat yang perlu dilakukan ritual $O \mathrm{ka}$ adalah (1) penjemputan hasil panen dari kebun; (2) penjemputan seseorang yang keluar dari penjara; (3) penjemputan tamu-tamu terhormat seperti tokoh pemerintah dan tokoh agama, dan (4) penjemputan material bangunan rumah adat berupa kayu yang ditebang dari hutan (Dairo, 2015: 2).

Salah satu fungsi ritual $\mathrm{Oka}$ adalah dalam peristiwa kembalinya seseorang dari penjara. Sebelum narapidana yang sudah bebas dari tahanan memasuki kampung atau rumah besar, dari pihak keluarga yang menerimanya kembali harus melakukan ritual $O k a$. Ritual $O k a$ ini dilakukan tepat di pintu gerbang kampung. Ritual Oka seperti ini dimaksudkan untuk membersihkan jiwa narapidana agar tidak terulang lagi perbuatan jahat yang pernah dilakukannya. Narapidana tersebut harus bertobat dan kembali kepada jalan yang benar. Selain itu, ritual $O K a$ ini dimaksudkan untuk mengangkat kembali jiwa dan martabat narapidana tersebut, dalam menempuh kehidupan yang lebih baik seperti semula dalam masyarakat. Dengan kata lain, $\mathrm{Oka}$ sebagai tradisi sosial kolektif masyarakat Wewewa memiliki makna khas karena di dalamnya terkandung seperangkat sistem sosial budaya dan 
nilai-nilai historis, moral, dan etika dalam menata pola hidup bermasyarakat. Apabila seseorang mengabaikan nilai-nilai atau pesan lisan yang terkandung dalam tradisi, tentu orang tersebut mendapatkan ganjaran yang ditunjukkan oleh alam dan leluhur dalam proses tradisi. Hal ini memberi pemahaman bahwa tradisi lisan ini merupakan manifestasi jati diri masyarakat Wewewa.

Pada era globalisasi ini, sejalan dengan perkembangan ilmu pengetahuan dan teknologi, banyak tradisi lisan di masyarakat manapun sudah mulai diabaikan bahkan ditinggalkan, termasuk tradisi lisan $\mathrm{Oka}$ yang ada pada masyarakat Wewewa. Warga masyarakat sudah mulai beranggapan bahwa memasukkan ritual $O \mathrm{Ka}$ dalam sebuah upacara penjemputan atau penyambutan membuat upacara itu menjadi lama karena generasi sekarang menginginkan sebuah upacara yang cepat dan singkat. Mereka tidak bertahan dengan suasana ritual yang lama dan panjang. Selain itu, hanya segelintir orang yang bisa membawakan ritual $O k a$ tersebut. Banyak yang kurang pandai membawakan ritual Oka. Salah satu yang menyebabkan banyak orang kurang pandai membawakan ritual OKa adalah kurangnya keterlibatan anak-anak atau kaum muda dalam seluruh proses ritual tersebut.

Tantangan nyata pada era globalisasi ini adalah semakin kompleksnya berbagai bidang kehidupan karena adanya teknologi informasi, komunikasi, dan transportasi yang membawa pengaruh terhadap berbagai nilai dan cakrawala masyarakat Wewewa. Tantangan globalisasi yang mendasar dan dihadapi, antara lain: (1) sikap individualisme, yaitu munculnya kecenderungan mengutamakan kepentingan diri sendiri di atas kepentingan bersama; (2) memudarnya semangat kerja sama, dan (3) menurunnya semangat solidaritas dan kesetiakawanan sosial serta gotong royong (Hidayati, 2016: 41). Selain itu, apresiasi generasi muda masyarakat Wewewa, yaitu banyaknya generasi muda yang sudah melupakan warisan berharga para leluhur dan jati diri masyarakatnya dengan fenomena baru, yaitu lebih mengenal hal-hal yang bersifat modern. Fenomena perubahan tersebut menggambarkan bahwa kekuatan tradisi lisan $\mathrm{Oka}$ terancam keberadaan dan kelestariannya. Bahkan, tradisi lisan ini sebagai salah satu produk dan praktik budaya warisan leluhur masyarakat Wewewa mengalami kepunahan. Hal ini sejalan dengan Mubah (2011: 5) yang mengatakan bahwa globalisasi harus disikapi dengan bijaksana sebagai hasil positif dari modernisasi yang mendorong masyarakat pada kemajuan. Namun, para pelaku budaya lokal tidak boleh lengah dan terlena karena era keterbukaan dan kebebasan itu juga menimbulkan pengaruh negatif yang merusak budaya bangsa. Pengaruh negatif itu misalnya karena tuntutan hidup yang menyebabkan mereka harus mencari pekerjaan ke pulau-pulau atau kota-kota besar lain.

Berdasarkan beberapa fenomena di atas, peneliti hendak mengkaji secara khusus dan mendalam tentang jati diri yang tercermin dalam tradisi lisan $\mathrm{Oka}$ dalam perspektif etnopragmatik. Goddard (2004) dalam Darmojuwono (2011: 3) mengatakan bahwa konsep etnopragmatik adalah proses masyarakat memahami makna ilokusional bahasa atau tuturan berdasarkan konteks budaya yang berhubungan dengan nilai-nilai kearifan lokal, kepercayaan, perilaku, kategori sosial, dan emosi (periksa Song (2010: 877).Selain itu, konteks situasi dapat digunakan untuk menggali apa yang terjadi, entitas yang terlibat dalam kegiatan tersebut, keadaan, di mana, dan kapan kegiatan itu terjadi(periksaHymes, 1972: 55-60;Made, 2011:37). Etnopragmatik menyoroti bagaimana peristiwa tradisi lisan $O k a$ agar dapat dimengerti dan dipahami dengan baik dari sudut pandang budaya masyarakat Wewewa.

\section{Metode}

Penelitian ini tergolong penelitian kualitatif yang dilaksanakan di lapangan (field re-search) dan sesuai objek serta tujuan yang ingin dicapai peneliti. Objek penelitian ini adalah jati diri masyarakat Wewewa yang termanifestasi dalam kearifan lokal pada tuturan-tuturan lisan Oka. Sumber data penelitian ini yaitu tradisi lisan $\mathrm{Oka}$ yang dituturkan tetua adat di wilayah Wewewa, Sumba Barat Daya, NTT. Data berupa bagianbagian dari tradisi lisan Oka yang diidentifikasi sebagai jati diri berdasarkan kesatuan makna kontekstual dari sumber data. Dalam pengumpulan data digunakan metode simak, teknik catat (Sudaryanto, 2015: 203-206). Untuk mendukung pemaknaan data dimanfaatkan metode percakapan etnografis, teknik catat (Harris dalam Spradley, 2006: 5). Metode analisis data ditempuh melalui metode padan ekstralingual, teknik analisis kontekstual, yakni metode dan teknik analisis bahasa dengan mengaitkan konteks budaya masyarakat Wewewa (periksa Mahsun, 2005: 120; Rahardi, 2009: 36). 
Analisis data penelitian ini ditempuh dalam beberapa tahap. Pertama transkripsi data, yakni peneliti mencatat semua data yang telah dikumpulkan menjadi corpus data. Kedua, penerjemahan gloss, yakni peneliti menerjemahkan gloss data ke dalam bahasa Indonesia. Ketiga, seleksi data, yakni peneliti menentukan data-data untuk dianalisis. Keempat, identifikasi data, yakni peneliti memilih data-data yang siap untuk dianalisis. Data-data diidentifikasi berdasarkan kesatuan makna pragmatik dan wujud identitas masyarakat Wewewa. Kelima, klasifikasi data, yakni peneliti mengelompokkan data berdasarkan unit-unit tujuan penelitian. Keenam, peneliti menganalisis dan menginterpretasi data sehingga dapat dilaporkan pada bagian pembahasan data.

\section{Hasil dan Pembahasan}

Tradisi lisan $\mathrm{Oka}$ merupakan lukisan nyata masyarakat Wewewa, karena tidak hanya mengungkapkan hal-hal yang bersifat permukaan saja, tetapi melukiskan karakter, jiwa masyarakat secara mendalam, yakni jati diri masyarakat Wewewa. Sesungguhnya segala bentuk identitas sosial atau jati diri masyarakat Wewewa termanifestasi dalam tuturan-tuturan lisan $\mathrm{Oka}$ sebagai bukti pewarisan nilai dari leluhur. Di pihak lain, tradisi lisan $O k a$ sebagai manifestasi jati diri masyarakat Wewewa sebagaimana diungkapkan dalam hipotesis Sapir-Whorf yang menegaskan bahwa bahasa menentukan corak suatu masyarakat (Rahardi 2006: 143). Artinya bahwa tradisi lisan Oka yang diwujudkan dalam tuturan-tuturan lisan $\mathrm{Oka}$ berpengaruh dalam pewarisan identitas masyarakat Wewewa. Jati diri atau identitas masyarakat Wewewa diungkapkan dalam bentuk tuturan-tuturan lisan OKa, oleh karena nenek moyang masyarakat Wewewa pada saat itu belum mengenal adanya tradisi tulis. Para leluhur mewariskannya dalam bentuk tuturan-tuturan lisan yang bisa mengungkapkan identitas sosial masyarakatnya. Apabila tuturan-tuturan lisan $\mathrm{Oka}$ tidak diwariskan maka masyarakat Wewewa tidak mengetahui, memahami, dan mengkomunikasikan jati diri atau identitas yang diwariskan oleh leluhurnya.

Saat mendalami tradisi lisan $O k a$, peneliti memahami bahwa banyak hal dalam tradisi lisan Oka yang memuat aspek etnografi kehidupan masyarakat Wewewa sebagai gambaran jati diri/identitas masyarakat mereka. Karena itu peneliti mengkaji secara mendalam identitas/jati diri masyarakat Wewewa yang termanifestasi dalam tuturan-tuturan lisan OKa. Peneliti menemukan ada tujuh jati diri yang menjadi jiwa/karakter masyarakat Wewewa yaitu penghormatan kepada leluhur, penghormatan kepada pemimpin, kerja keras, pertobatan anak yang hilang,kebersamaan, pengucapan syukur, dan kekeluargaan.

\section{Penghormatan kepada Leluhur}

Dalam Kamus Besar Bahasa Indonesia (2008), kata penghormatan berarti (1) proses, cara, perbuatan menghormati (2) pemberian hormat. Sementara itu, kata leluhur berarti nenek moyang. Penghormatan kepada leluhur berarti pemberian hormat kepada nenek moyang. Hal ini senada dengan informan dalam (W/JDMW/1) mengatakan bahwa penghormatan kepada leluhur adalah penghormatan kepada orang yang telah meninggal dunia didasarkan kecintaan dan rasa hormat kepada mereka. Dalam beberapa budaya hal ini berkaitan dengan keyakinan dan kepercayaan bahwa mereka yang telah meninggal memiliki kehidupan yang berkelanjutan, serta memiliki kemampuan untuk mempengaruhi keberuntungan mereka yang masih hidup di dunia.

Jebadu (2009: 9) mengatakan bahwa penghormatan kepada leluhur dilihat sebagai wujud dari model keberimanan yang dibawa manusia dari generasi sebelumnya. Maka fungsi sosial dari penghormatan kepada leluhur adalah untuk menumbuhkan nilai-nilai kekerabatan seperti bakti, kesetiaan keluarga, dan kesinambungan garis keturunan keluarga. Demikian juga dalam masyarakat Wewewa, penghormatan kepada leluhur sungguh berakar dalam seluruh kehidupan mereka dan termanifestasi dalam tuturan-tuturan tradisi lisan mereka.Hal ini tercermin dalam tuturan lisan $O k a$ di bawah ini.

"Dyoooo... Nggara nggu ole a lolungo malawo mangu ana, a burungo tawewe mangu tollu. Tau!"

"Halo... Siapa kamu yang datang beriringan dan berbondong-bondong? Jawablah!” (A1B).

Konteks:

Tuturan tersebut diungkapkan oleh tetua adat sebagai tuan rumah yang bertanya ketika menyambut masyarakat yang membawa hasil panen. Ritual ini diadakan 
di pintu gerbang pada sore hari. Mitra tutur dalam ritual ini adalah tetua adat yang menjawab mewakili masyarakat yang membawa hasil panen. Tujuan dari ritual ini untuk menyambut masyarakat sebelum hasil panen dibawa masuk ke rumah besar. Ritual ini dilaksanakan dalam suasana gembira dengan "payawau pakalakka" (seruan kegembiraan yang dilakukan oleh kaum pria maupun wanita). Media yang digunakan dalam ritual ini adalah tuturantuturan lisan dalam bentuk Tanya-jawab antara tetua adat yang bertanya dengan tetua adat yang menjawab. Ritual ini diawali dengan sapaan "dyooo" yang berarti "halo" dan diakhiri dengan kata "tau" yang berarti "jawablah".

Dalam tuturan lisan (A1B) di atas, terhadap rombongan masyarakat yang datang membawa hasil panen, tetua adat menyambut mereka dengan ungkapan yang beriring bagai tikus membawa anaknya, bagai ayam hutan membawa telurnya. Tuturan tersebut secara tidak langsung sebenarnya menunjuk kepada leluhur. "Beriring bagai tikus membawa anaknya, bagai ayam hutan membawa telurnya", sejatinya merupakan kearifan lokal tak berwujud (intangible) berupa perumpamaan yang menunjuk pada entitas tak kelihatan yaitu leluhur. Tetua adat mau menghadirkan para leluhur dalam seluruh peristiwa hidup mereka. Hal ini senada dengan yang dikatakan Hayon (1970: 26) bahwa dalam kehidupan sehari-hari masyarakat Wewewa, nenek moyang mempunyai pengaruh yang amat besar. Hubungan dengan nenek moyang amat menentukan kehidupan mereka. Untuk memelihara hubungan baik dengan nenek moyang, mereka harus berusaha memberi penghormatan yang selayaknya.

Sementara Neonbasu (2016: 70) mengatakan bahwa penghormatan kepada leluhur erat kaitannya dengan kepercayaan Marapu. Marapu adalah arwah dari para leluhur yang bertindak sebagai Dikita yaitu pengantara antara manusia dengan yang ilahi (magholo marawi). Peranannya adalah menciptakan, memelihara, melimpahkan rezeki, keturunan, kesehatan, dan menetapkan umur manusia dan semua makluk ciptaan lain. Citra Dikita diyakini sebagai para leluhur yang sudah mengalami perjumpaan dengan Magholo Marawi. Artinya, diyakini bahwa para leluhur tersebut ketika selagi masih hidup di bumi, suci hatinya, sakti dan tidak pernah berbuat jahat. Jati diri penghormatan kepada leluhur dalam masyarakat Wewewa, sesungguhnya diperoleh dari makna pragmatik yaitu menyapa leluhur karena leluhur diyakini telah memberikan berkat panenan yang berlimpah, padi yang bernas dan jagung yang berisi. Jati diri penghormatan kepada leluhur diperoleh juga saat menyambut narapidana yang baru keluar dari penjara. Hal ini termanifestasi dalam tuturan lisan $O k a$ berikut ini.

"Dyoooo... Nggara nggu neme a rarana mareaa kambu loda, a meta kandawu pada. Nggara nggu neme aringngu la nggoro na a widu pandina, nena mbali binna mone, nena puu kawango dassa. Nggara nggu a pakassa na kaka mbali binna mone a kangole na pero puu kawango dassa. Tau!'” "Halo... Siapa kamu yang datang dengan pakaian warna-warni, yang datang diringi bunyi gong dan tambur, yang berkumpul dalam rombongan banyak orang? Jawablah!” (B1B).

Konteks:

Tuturan tersebut diungkapkan oleh tetua adat sebagai tuan rumah yang bertanya ketika menyambut narapidana yang keluar dari penjara kembali ke kampungnya bersama rombongan. Ritual ini diadakan di pintu gerbang pada pagi hari. Mitra tutur dalam tuturan ini adalah tetua adat yang menjawab mewakili narapidana dan rombongan. Tujuan dari ritual ini adalah menyambut kehadiran narapidana sebelum masuk ke kampung. Ritual ini terjadi dalam suasana haru, empati, dan gembira dengan "payawau pakalakka" (seruan kegembiraan yang dilakukan oleh kaum pria maupun wanita). Media yang digunakan dalam tuturan ini adalah tuturan-tuturan lisan dalam bentuk tanya-jawab antara tetua adat yang bertanya dan tetua adat yang menjawab. Ritual ini diawali dengan sapaan "dyooo" yang berarti "halo" dan diakhiri dengan kata "tau" yang berarti "jawablah".

Dalam tuturan lisan (B1B) di atas, terhadap narapidana dan rombongan, tetua adat menyambut mereka dengan ungkapan yang datang, yang memerahkan padang dan yang menghijaukan 
hutan. Tuturan tersebut secara tidak langsung, sebagai bentuk penghormatan kepada leluhur. Tuturan "yang memerahkan padang, yang menghijaukan hutan" sesungguhnya merupakan kearifan lokal tidak berwujud (intangible) berupa perumpamaan yang menunjuk pada entitas tak kelihatan yaitu leluhur. Tatanan hidup bermasyarakat yang telah rusak lewat sikap dan perbuatan manusia seperti membunuh, mencuri, dan merampok, dipulihkan kembali dengan kehadiran leluhur dalam diri narapidana. Hal ini senada dengan Ujan (2012: 19) yang mengemukakan bahwa kerharmonisan dan keteraturan dalam tatanan hidup bermasyarakat itu ada, bila terjamin suatu hubungan yang erat dan mesra antara mereka dengan ina-ama (leluhur). Jati diri penghormatan kepada leluhur diperoleh juga saat menyambut uskup sebagai pemimpin gereja. Hal ini termanifestasi dalam tuturan lisan $O K a$ berikut ini.

"Dyoooo... Nggara nggu a rarana maredda kambu loda, amorona kandawu kambu pada. Nggara nggu a ringula gorona, a widu pandina. Nggara nggu a pakassana kaka mbali binna mone, a kangole na pero puu kawango dassa. Tau!"

"Halo... Siapa kamu yang datang dalam rombongan banyak orang, dengan pakaian warna-warni, dengan bunyi gong dan tambur? Jawablah!” (C1B).

\section{Konteks:}

Tuturan tersebut diungkapkan oleh tetua adat sebagai tuan rumah yang bertanya ketika menyambut uskup sebagai pemimpin gereja setempat yang berkunjung di sebuah paroki. Ritual ini diadakan di pintu gerbang pada pagi hari. Mitra tutur dalam tuturan ini adalah tetua adat yang menjawab mewakili uskup dan rombongan. Tujuan dari ritual ini adalah untuk menyambut uskup sebagai pemimpin gereja yang datang mengunjungi umatnya dan pelayanan sakramen gereja. Suasana dalam ritual ini penuh sukacita dengan "payawau pakalakka" (seruan kegembiraan yang dilakukan oleh kaum pria maupun wanita). Media yang digunakan dalam ritual ini adalah tuturan-tuturan lisan dalam bentuk tanyajawab antara tetua adat yang bertanya dengan tetua adat yang menjawab.
Ritual ini diawali dengan sapaan "dyooo" yang berarti "halo" dan diakhiri dengan kata "tau" yang berarti "jawablah".

Dalam tuturan lisan (C1B) di atas, terhadap uskup dan rombongan, tetua adat menyambut mereka dengan ungkapan yang datang berkumpul bagai kakatua dan bergerombol bagai nuri di pohon waru yang rindang. Tuturan tersebut secara tidak langsung sebagai bentuk ungkapan penghormatan kepada leluhur. Tuturan "berkumpul bagai kakatua, bergerombol bagai nuri di pohon waru yang rindang", sejatinya merupakan kearifan lokal yang tidak berwujud (intangible) berupa perumpamaan yang menunjuk pada entitas tak kelihatan yaitu leluhur. Lewat tuturan itu, leluhur diyakini telah diundang untuk datang dan hadir dalam diri uskup sebagai pemimpin gereja setempat yang datang berkunjung dan berdialog dengan umatnya. Hal ini senada dengan yang dikatakan oleh Choiriyati (2017: 82) bahwa bentuk komunikasi apapun yang disampaikan oleh pemimpin merupakan perintah dari Allah yang disampaikan melalui leluhur. Eksistensi leluhur menjadi sangat penting dalam seluruh aspek kehidupan manusia. Jati diri penghormatan kepada leluhur diperoleh juga saat menyambut bupati sebagai pemimpin wilayah. Hal ini tercermin dalam tuturan lisan $\mathrm{Oka}$ berikut ini.

"Dyoooo... Nggara nggu ole a lolungo malawo, nggara nggu ole a burungo tawewe. Nggara nggu neme a zowa ana rande na, nggara nggu nema a lolu ana wawi na. A meta kambu pada, a rara kambu loda. Tau!"

"Halo... Siapa kamu yang datang dalam rombongan banyak orang, yang datang beriringan dan berkelompok dengan pakaian warna-warni. Jawablah!" (D1B)

Konteks:

Tuturan tersebut diungkapkan oleh tetua adat sebagai tuan rumah yang bertanya ketika menyambut bupati sebagai pemimpin wilayah yang berkunjung di sebuah desa. Ritual ini diadakan di pintu gerbang pagi hari. Mitra tutur dalam tuturan ini adalah tetua adat yang menjawab mewakili bupati dan rombongan. Tujuan ritual ini adalah menyambut bupati yang datang mengunjungi masyarakat. Suasana dalam ritual ini penuh sukacita 
dengan "payawau pakalakka" (seruan kegembiraan yang dilakukan oleh kaum pria maupun wanita). Media yang digunakan dalam ritual ini adalah tuturantuturan lisan dalam bentuk Tanya jawab antara tetua adat yang bertanya dengan tetua adat yang menjawab. Ritual ini diawali dengan sapaan "dyooo" yang berarti "halo" dan diakhiri dengan kata "tau" yang berarti "jawablah".

Dalam tuturan lisan (D1B) di atas, terhadap bupati dan rombongan, tetua adat menyambut mereka dengan ungkapan yang datang beriringan bagai tikus membawa anaknya, bagai ayam hutan membawa telurnya. Yang datang bergerombol bagai anak itik dan berbaris bagai anak babi. Tuturan "bergerombol bagai anak itik dan berbaris bagai anak babi", sesunggunya merupakan kearifan lokal yang tak berwujud (intangible) berupa perumpamaan yang menunjuk pada entitas tak kelihatan yaitu leluhur. Tuturan tersebut secara tidak langsung sebagai bentuk ungkapan penghormatan kepada leluhur, agar ada dan hadir dalam diri bupati sebagai pemimpin wilayah setempat yang datang berkunjung dan berdialog dengan masyarakatnya. Bupati sebagai pemimpin wailayah hendaknya bersentuhan dengan budaya, bahwa nilai-nilai budaya masyarakat Wewewa mempunyai andil dalam membentuk persepsi individu dan kelompok terhadap pemimpin dan kepemimpinannya. Hal ini sejalan dengan yang dikatakan Vilkinas (2009) dalam Mulyani (2016: 455) bahwa budaya manapun, kepemimpinan dipengaruhi oleh budaya. Artinya nilai-nilai budaya dan kearifan lokal masyarakat Wewewa turut andil dalam membentuk persepsi individu dan kelompok terhadap pemimpin dan kepemimpinan etnik Wewewa. Jati diri penghormatan kepada leluhur diperoleh juga saat menyambut rombongan yang membawa material bangunan. Hal ini tercermin dalam tuturan lisan $\mathrm{Oka}$ berikut ini.

"Dyoooo... Nggara nggu a waina nggiri loddo, nggarra nggu a waina male tana. A rara na mareda kambu loda, a meta kandawu kambu pada. Bau lolungo malawo, bau burungo tawewe. A waina kapuka waicogo, a waina peda raka wawi. Mbale angga panewe, nonga angga kandauka. Tau!"

"Halo... Siapa kamu yang datang dengan pakaian berwarna warni, yang datang dalam rombongan banyak orang, yang datang sambil menyanyikan yelyel. Jawablah!” (E1B).

Konteks:

Tuturan tersebut diungkapkan oleh tetua adat sebagai tuan rumah yang bertanya ketika menyambut masyarakat yang membawa material bangunan dari hutan. Ritual ini dilaksanakan di pintu gerbang kampung pada sore hari. Mitra tutur dalam ritual ini adalah tetua adat yang menjawab mewakili masyarakat yang membawa material bangunan. Tujuan ritual ini untuk menyambut masyarakat sebelum material bangunan dibawa masuk ke kampung. Ritual ini dilaksanakan dalam suasana gembira dengan "payawau pakalakka" (ungkapan atau seruan kegembiraan yang dilakukan oleh kaum pria maupun wanita). Media yang digunakan dalam ritual ini adalah tuturan-tuturan lisan dalam bentuk Tanya jawab antara tetua adat yang bertanya dan tetua adat yang menjawab. Ritual ini diawali dengan sapaan "dyooo", yang berarti "halo" dan diakhiri dengan kata "tau" yang berarti "jawablah".

Dalam tuturan lisan (E1B) di atas, terhadap rombongan yang membawa material bangunan, tetua adat menyambut mereka dengan ungkapan yang datang, memerahkan padang dan yang menghijaukan hutan. Tuturan tersebut secara tidak langsung sebagai bentuk ungkapan penghormatan kepada leluhur, yang telah mendapingi dan menyertai anggota keluarga dalam mencari dan mendapatkan material bangunan, seperti kayu, alang, tali, dan lain-lain. Para leluhur senantiasa hadir dalam seluruh kehidupan mereka. Hal ini senada dengan yang dikatakan Hayon (1970: 26) bahwa dalam kehidupan masyarakat sehari-hari dalam masyarakat Wewewa, nenek moyang dianggap mempunyai pengaruh yang amat besar. Hubungan dengan nenek moyang amat menentukan kehidupan mereka. Untuk memelihara hubungan baik dengan nenek moyang, mereka harus berusaha memberi penghormatan yang selayaknya.

Jati diri masyarakat Wewewa tentang penghormatan kepada leluhur, sungguh-sungguh berakar dalam kehidupan mereka sehari-hari. Leluhur memiliki peran yang sangat penting, karena memiliki pengaruh yang amat besar. Oleh 
karena itu, menghadirkan keberadaan leluhur dalam peristiwa-peristiwa yang terjadi dalam seluruh hidup masyarakat Wewewa merupakan keharusan dan mutlak diperlukan bagi mereka.

\section{Penghormatan kepada Pemimpin}

Dalam Kamus Besar Bahasa Indonesia (2008), kata penghormatan berarti (1) proses, cara, perbuatan menghormati (2) pemberian hormat. Sementara itu, kata pemimpin berarti orang yang memimpin. Penghormatan kepada pemimpin adalah pemberian hormat kepada orang yang memimpin. Dalam konteks uskup sebagai pemimpin gereja dan bupati sebagai pemimpin wilayah dipahami sebagai orang yang ditunjuk dan terpilih untuk memimpin gereja dan wilayah.

Pemimpin adalah orang yang mengemban tugas dan tanggungjawab untuk memimpin dan bisa mempengaruhi orang yang dipimpinnya. Hal ini sejalan dengan Daswati (2012: 784) yang mengatakan bahwa pemimpin memiliki tanggung jawab yang besar terhadap pencapaian tujuan. Demikian juga dengan Kartono (1990: 64) yang mengatakan bahwa pemimpin adalah seorang pribadi yang memiliki cakapan kelebihan dalam suatu bidang, sehingga dia mampu mempengaruhi orang lain untuk bersama-sama melakukan aktivitas-aktivitas tertentu.

Menjadi seorang pemimpin berarti harus siap untuk menjadi pelayan, pangayom, dan pengabdi masyarakat.Dalam masyarakat Wewewa, dua tokoh pemimpin ini senantiasa hadir dalam kehidupan mereka yaitu uskup sebagai pemimpin gereja dan bupati sebagai pemimpin wilayah. Uskup sebagai pemimpin gereja adalah pelayan spiritual yang senantiasa mengarahkan dan membimbing umat untuk hidup surgawi. Hal ini nyata dalam tuturan $\mathrm{Oka}$ berikut ini.

"Malla! Inda tawe kimo tana, inda wenna kimo watu. Kalli ukku nawe benge moddu, kalli pata nawe lero dinga. Bama pote papa kassa na mbali binna mone, bama wula pa kangole na pu'u kawango dassa. Inna mungga, amma mungga, a neena tara manu ulle wawi, a wali likku lai palonda a wali amba luna lele. A lira mbali mbapa we wali kasikku tana Ngapu, a baba kado kenga we duki kiku tana Kyodi, papa powi api loddo, pa pandita wee gedde. Ama muni inda tukku kina bina mora, ba katanga ko ngenge ngora mbali bina mone, Inna muni inda bera kina ndOka kaka, ba katanga ko ngenge ngorana puu kawango dassa. Peina?" "Baiklah! Saya yang datang adalah ibu dan bapak yang mendiami rumah besar di tanah Loura. Saya adalah orang yang memimpin dan menggembalai dari ujung Sumba Timur hingga tanah Kodi. Orang yang membawa terang dan kesejukan. Saya bukanlah musuh atau lawan. Saya datang untuk menguatkan dan meneguhkan iman dan kepercayaan kamu. Maka bukakanlah saya pintu, lapangkan saya jalan. Bagaimana?" (C2I).

\section{Konteks:}

Tuturan tersebut diungkapkan oleh tetua adat yang mewakili uskup ketika menjawab pertanyaan dari tetua adat yang mewakili tuan rumah saat menyambut uskup sebagai pemimpin gereja setempat. Ritual ini terjadi di pintu gerbang pada pagi hari. Mitra tutur dalam tuturan ini adalah tetua adat yang bertanya. Tujuan ritual ini adalah menungkapkan statu diri dan tugas uskup sebagai pemimpin gereja setempat. Suasana dipenuhi dengan keakraban, persaudaraan, dan sukacita dengan "payawau pakallaka" oleh kaum pria dan wanita. Media dalam ritual ini adalah tuturan-tuturan lisan yang diungkapkan dalam bentuk tanyajawab antara tetua adat yang menjawab dengan tetua adat yang bertanya. Tuturan ini diawali dengan kata "malla" yang berarti "baiklah" dan diakhiri dengan kata "peina" artinya "bagaimana".

Dalam tuturan (C2I) di atas, nampak jelas jati diri masyarakat Wewewa yaitu penghormatan kepada pemimpin. Bentuk penghormatan mereka kepada uskup sebagai pemimpin gereja dengan mengakui kewibawaannya sebagai gembala diumpamakan dengan orang yang menghidupkan api di siang hari dan yang menimba air di malam hari. Tuturan "yang menghidupkan api di siang hari dan yang menimba air di malam hari", sejatinya adalah bentuk kearifan lokal yang tidak berwujud (intangible) berupa perumpamaan berkaitan dengan tugas dan tanggung jawab seorang pemimpin spiritual yaitu uskup. Suatu tugas dan tanggung jawab yang tidak ringan. Uskup adalah gembala yang baik, yang siap menghantarkan dombadombanya ke padang rumput yang hijau dan ke sumber air yang menyegarkan (Mazmur 23). 
Demikian juga dengan bupati sebagai pemimpin wilayah setempat. Bupati sebagai pemimpin dan abdi masyarakat yang mengayomi dan senantiasa berjuang untuk kesejahteraan dan kemakmuran masyarakatnya. Hal ini nyata dalam tuturan $O k a$ di bawah ini.

"Malla! Ne bamu kadde londa koko, bautua londa ate. Ne ta delaka na tana, neta wanggara na loddo. Tawe inda tawe kimo tana, wewu inda wewu kimo watu. Yauwa dona inna mungga, ama mungga. Mai ngguwe pa totoka paredda, ma nggeloka pa ngadu. Wali ngguwe pa powi api loddo, neme kadula mananga, wali ngguwe pa ndita wee gedde, ne ryawa mawa bondo. Yauwa dona inna a baba kaddo kenga we. Loda weimaringi, a lira mbali mbapawe pada wei malala Yauwa dona inna leiro loko, yauwa dona ama tema tana Lunggu nggu nenna inna pa toma, lunggu nggu nenna ama pa dukki. Peina?"

"Baiklah! Kamu bertanya dan menyelidiki. Saya adalah ibu dan bapak yang mau berkunjung. Saya adalah pelayan dan abdi masyarakat. Saya adalah pemimpin wilayah. Saya datang berkunjung mau melihat kamu semua bekerja. Maka, bukakanlah saya pintu, lapangkan saya jalan. Bagaimana?" (D2I).

\section{Konteks:}

Tuturan tersebut diungkapkan oleh tetua adat yang mewakili bupati ketika menjawab pertanyaan dari tetua adat yang mewakili tuan rumah saat menyambut bupati sebagai pemimpin wilayah setempat yang datang berkunjung. Ritual ini terjadi di pintu gerbang pada pagi hari. Mitra tutur dalam tuturan ini adalah tetua adat yang bertanya. Tujuan ritual ini adalah mengungkapkan status diri dan tugas bupat sebagai pemimpin wilayah. Suasana penuh keakraban, persaudaraan, dan sukacita dengan "payawau pakallaka" oleh kaum pria dan wanita. Media dalam ritual ini adalah tuturan-tuturan lisan yang disampaikan dalam bentuk tanyajawab antara tetua adat yang menjawab dengan tetua adat yang bertanya. Tuturan ini diawali dengan kata "malla" yang berarti "baiklah" dan diakhiri dengan kata "peina" artinya "bagaimana".

Dalam tuturan (D2I) di atas, nampak jelas jati diri masyarakat Wewewa yaitu penghormatan kepada pemimpin. Bentuk penghormatan mereka kepada bupati sebagai pemimpin wilayah dengan mengakui kewibawaannya sebagai ibu dan bapa, diumpamakan dengan yang memangku tanah terberkati loda weemaringi, pada weemalala. Tanah yang subur dan sumber daya alam daerah senantiasa diupayakan oleh pemimpin dalam hal ini pemerintah, untuk kemakmuran dan kesejahteraan rakyat. Suatu tugas dan tanggung jawab yang tidak mudah bagi seorang pemimpin wilayah dalam berkoordinasi dengan seluruh elemen masyarakat. Bupati sebagai pemangku wilayah diharapkan merangkul seluruh elemen masyarakat untuk sehati dan sejiwa membangun masyarakat. Hal ini sesuai dengan yang dikemumkakan oleh Rivai dalam Fazrien (dkk) (2015: 603) mengenai fungsi koordinasi seorang pemimpin yaitu menghubungkan, menyatupadukan, menyelaraskan hubungan antara orang-orang, pekerjaan-pekerjaan dan satuan-satuan organisasi yang satu dengan yang lain sehingga semuanya berjalan harmonis.

Jati diri masyarakat Wewewa tentang penghormatan kepada pemimpin, khususnya kepada uskup sebagai pemimpin gereja dan bupati sebagai pemimpin wilayah sungguh berakar dalam kehidupan mereka sehari-hari. Pemimpin memiliki peran yang sangat penting, karena memiliki pengaruh yang amat besar. Oleh karena itu, penghormatan kepada pemimpin dalam masyarakat Wewewa merupakan keharusan dan mutlak diperlukan bagi mereka.

\section{Kerja Keras}

Dalam Kamus Besar Bahasa Indonesia (2008), kata kerja berarti (1) kegiatan melakukan sesuatu: yang dilakukan/yang diperbuat (2) sesuatu yang dilakukan untuk mencari nafkah; mata pencaharian. Sementara itu, kata keras berarti (1) padat kuat dan tidak mudah berubah bentuknya atau tidak mudah pecah (2) gigih; sungguh-sungguh hati. Maka kerja keras adalah kegiatan melakukan sesuatu dengan gigih atau dengan sungguh-sungguh hati.

Kerja keras adalah kegiatan yang dikerjakan secara sungguh-sungguh tanpa mengenal lelah atau berhenti sebelum target kerja tercapai dan selalu mengutamakan atau 
memperhatikan kepuasan hasil pada setiap kegiatan yang dilakukan. Hal ini senada dengan yang dikemukakan Ikhwanuddin (2012: 156) yang memaknai bahwa kerja keras adalah kerja penuh semangat dan tak kenal putus asa apabila menemui kegagalan. Hal senada ditegaskan informan (W/JDMW/5) bahwa kerja keras bagi masyarakat Wewewa adalah bekerja sungguh-sungguh untuk mencapai sasaran yang ingin dicapai. Mereka dapat memanfaatkan waktu optimal sehingga kadangkadang tidak mengenal waktu, jarak, dan kesulitan yang dihadapainya. Mereka sangat bersemangat dan berusaha keras untuk meraih hasil yang baik dan maksimal. Semangat juang dan kerja keras adalah jati diri masyarakat Wewewa. Hal ini dapat ditelusuri dalam tuturan lisan $\mathrm{Oka}$ berikut ini.

"Malla! Nenna inna patona nggu, nenna ama padukki nggu. A kaddi ngga koko, a zosi ngga ate. Yamme dona ana allimu, a wali ndari tana, a wali batu ruta. Kaku tallara kadinda mera tana ndi, kaku wewara maroto mburu urra ndi. Peina?"

"Baiklah! Kami yang datang adalah anakanakmu yang pulang dari mengolah tanah dan mencabut rumput. Kami yang menyebarkan biji jeruk di musim hujan. Kami bekerja keras. Sekarang daunnya sudah menguning dan buahnya sudah matang. Kami sudah tiba di bale-bale rumah. Bukakan kami pintu, lapangkan kami jalan. Bagaimana?" (A2I)

\section{Konteks:}

Tuturan tersebut diungkapkan oleh tetua adat ketika menjawab pertanyaan dari tetua adat wakil tuan rumah saat menyambut masyarakat yang membawa hasil panen. Ritual $O k a$ ini terjadi di pintu gerbang pada sore hari. Mitra tutur yaitu tetua adat yang bertanya. Tujuan dari ritual $\mathrm{Oka}$ ini adalah mengungkapkan kepada tuan rumah tentang usaha dan kerja keras mereka hingga memetik hasil. Suasana dalam ritual ini dipenuhi sukacita dengan "payawau pakallaka" oleh kaum pria dan wanita. Media dalam ritual ini adalah tuturantuturan lisan yang disampaikan dalam bentuk tanyajawab antara tetua adat yang menjawab dengan tetua adat yang bertanya. Tuturan ini diawali dengan kata "malla" yang berarti "baiklah" dan diakhiri dengan kata "peina" artinya "bagaimana".
Dalam tuturan lisan (A2I) tersebut, ditunjukkan dengan sangat jelas identitas atau jati diri masyarakat Wewewa yang memiliki semangat juang dan kerja keras. Hal itu dieksplisitkan melalui tuturan "Kami ini adalah anak-anakmu yang pulang dari mengolah tanah dan mencabut rumput. Kami menyebarkan biji jeruk di musim hujan. Kami bekerja keras sampai musim panen tiba untuk menuai hasil". Tuturan "mengolah tanah, mencabut rumput, dan menyebar biji jeruk di musim hujan", sejatinya merupakan bentuk kearifan lokal yang tidak berwujud (intangible) berupa petuah yang ditujukan kepada anak-anak, keluarga, dan masyarakat agraris untuk senantiasa bekerja keras dan berjuang agar dapat meraih kesuksesan misalnya memperoleh panen yang berlimpah. Chaplin (1993) sebagaimana dikutip Asnawi (1999: 87) menegaskan bahwa semangat kerja merupakan sikap dalam bekerja yang ditandai secara khas dengan adanya kepercayaan diri, motivasi diri yang kuat untuk meneruskan pekerjaan, kegembiraan, dan organisasi yang baik. Sebagaimana tampak dalam tuturan tersebut, entitas agraris masyarakat Wewewa mengakui bahwa mereka adalah entitas yang menjunjung tinggi budaya bekerja keras melalui tahap demi tahap sampai menuai panenan. Hal itu juga ditunjukkan dalam tuturan lisan $\mathrm{Oka}$ menjemput material bangunan di bawah ini.

"Malla! Yamme dona a wali loda a panumbu, yamme dona a wali pada a panengga. Yamme dona wolla riwu rawu, a matallara puu ponda erri walli ndari tana. Yamme dona wua ta nenda tana, a mawesara mata mboro bisa wali batu ruta. Oro nawe, bana karewe ebana, bana karawu longgena, ne umma katonga da inna ama. Nggai kama tenduka na wasu, kama zerona ngaingo. Wali mawe mawengga wewa kama ponggo wasu a nggasu, wali mawe mandaba dala kama rata ngge kalerre a kalokko. Ndaiki winda rara witi, ndaiki windura kala. Niawe kana sannara ta wee, ndibbala ta mara. Kama kedu ngge bodora, wawi ngge bullura. Inda kaka mbali lete kiama, inda wondo mbali ala kiama. Inda kedu mai pawunu, inda wawi mai pangasa kiama. Peina?"

"Baiklah! Kamu bertanya dan menyelidiki. Kami yang datang adalah anak cucu yang tersebar di kebun. Karena rumah ibu dan bapak sudah rusak, maka kami akan 
membangun kembali. Kami baru kembali dari hutan, menebang kayu, mencari tali dan mengikat alang. Dalam usaha itu kami tidak menemukan halangan dan rintangan. Kami berjuang dan bekerja keras. Jadi sekarang kami sudah tiba di kampung. Kami datang berbondong-bondong. Kami bukan orang asing, bukan perusak dan pengganggu. Bukakanlah kami pintu, lapangkan kami jalan. Kami mau masuk untuk membangun kembali rumah ibu dan bapa. Bagaimana?" (E2I).

\section{Konteks:}

Tuturan tersebut diungkapkan oleh tetua adat yang mewakili rombongan pembawa material bangunan ketika menjawab pertanyaan dari tetua adat saat menyambut rombongan yang baru saja pulang dari hutan membawa material bangunan. Ritual ini terjadi di pintu gerbang pada sore hari. Mitra tutur dalam tuturan ini adalah tetua adat yang bertanya. Tujuan ritual mengungkapkan semangat juang dan kerja keras anak-anak dan keluarga sampai mendapatkan material bangunan. Suasana penuh keakraban, persaudaraan, dan sukacita dengan "payawau pakallaka" oleh kaum pria dan wanita. Media dalam ritual ini adalah tuturan-tuturan lisan yang disampaikan dalam bentuk tanyajawab antara tetua adat yang menjawab dengan tetua adat yang bertanya. Tuturanini diawali dengan kata "malla" yang berarti "baiklah" dan diakhiri dengan kata "peina" artinya "bagaimana".

Dalam tuturan lisan (E2I) tersebut, ditunjukkan dengan sangat jelas identitas atau jati diri masyarakat Wewewa yang memiliki semangat juang dan kerja keras dalam tuturan kami yang datang adalah anak cucu yang tersebar di kebun. Kami baru kembali dari hutan, menebang kayu, mencari tali dan mengikat alang. Dalam usaha itu kami tidak menemukan halangan dan rintangan. Kami berjuang dan bekerja keras. Tuturan "kami baru kembali dari hutan, menebang kayu, mencari tali, dan mengikat alang", sejatinya adalah bentuk kearifan lokal yang tidak berwujud (intangible) berupa petuah yang menunjuk kepada anak-anak, keluarga, dan warga masyarakat agar menunjung tinggi semangat kerja keras dan memiliki daya juang agar dapat meraih keberhasilan membangun sebuah rumah kediaman yang layak. Terkait dengan budaya kerja keras, Salaki (2014: 51) dalam kajiannya membangun karakter generasi muda melalui budaya Mapalus Suku Minahasa mengatakan bahwa nilai kerja keras bersama menjadi kewajiban setiap warga masyarakat. Semangat kerja keras harus dijiwai dalam seluruh kehidupan mereka. Demikian juga, pada masyarakat Wewewa, semangat kerja keras sudah menjadi jati diri mereka. Hal serupa juga ditegaskan oleh informan (W/JDMW/5) bahwa kerja keras bagi masyarakat Wewewa adalah bekerja sungguh-sungguh untuk mencapai sasaran yang ingin dicapai. Mereka dapat memanfaatkan waktu optimal sehingga kadang-kadang tidak mengenal waktu, jarak, dan kesulitan yang dihadapainya. Mereka sangat bersemangat dan berusaha keras untuk meraih hasil yang baik dan maksimal. Semangat ini senantiasa ditunjukkan lewat bekerja sekuat tenaga dengan dimotori oleh sebuah semangat yang berlandaskan semangat yang tak kunjung padam guna meningkatkan harkat, martabat dan harga diri sebagai manusia yang utuh (Syamsuddin, 2010: 189).

\section{Pertobatan Anak yang Hilang}

Perubahan pikiran dan hati yang membawa sikap yang baru terhadap diri sendiri, dan kehidupan secara umum. Kamus Besar Bahasa Indonesia (2008) terbitan Balai Pustaka, kata pertobatan merupakan turunan dari kata dasar tobat yang berarti (1) sadar dan menyesal akan dosa dan berniat akan memperbaiki tingkah laku dan perbuatan (2) kembali kepada agama, jalan, hal yang benar (3) merasa tidak sanggup lagi (4) menyatakan rasa heran, kesan atau sebal (5) jera, tidak akan berbuat lagi. Munthe (1996: 8) mengatakan bahwa pertobatan mengandung arti bahwa seseorang berpaling dari yang jahat serta memalingkan hati dan kehendaknya kepada yang baik dan yang benar. Perumpamaan tentang anak yang hilang (Lukas 15:11-32) bisa menjadi rujukan bagi segenap umat manusia yang mengajarkan tentang kesetiaan dan ketaatan kepada Allah. Ketika orang menyimpang dari Allah haruslah segera berbalik kembali kepada Allah. Dan setiap orang yang hilang dapat kembali kepada Allah karena Allah menerima orang yang mau datang kembali kepada Allah. Pertobatan anak yang hilang adalah jati diri masyarakat Wewewa. Hal ini dapat ditelusuri dalam tuturan lisan Oka di berikut ini. 
"Malla! Yauwa dona, ana pa pana na pare inna, ana pa pasusu na lelu ama. Yauwa dona, a wali neme gollu ana wawi, ne bubaku maringu. Yauwa dona, a wali neme koro ana manu, ne kalinda gollu ndima. Inda kaka mbali lete kianga, inda wondo mbali ala kiangga. Inda kedu mai pawunu, inda wawi wai pangasa kiama. Peina?"

Saya yang datang adalah anak dari ibu dan bapak yang melahirkan. Saya datang dari sel penjara di Waikabubak Loli. Saya bukan orang asing yang datang untuk mengganggu dan menghambat. Saya masuk penjara karena saya telah membunuh orang. Karena waktu hukuman telah selesai, saya mau kembali pulang ke rumah, kembali kepada ibu dan bapak. Bukakanlah saya pintu, lapangkan saya jalan. Bagaimana?" (B2I)

\section{Konteks:}

Tuturan tersebut diungkapkan oleh tetua adat ketika menjawab pertanyaan dari tetua adat wakil tuan rumah saat menyambut narapidana dan rombongan. Ritual ini terjadi di pintu gerbang pada pagi hari. Mitra tutur dalam tuturan ini adalah tetua adat yang bertanya. Tujuan dari ritual ini adalah mengungkapkan rasa penyesalan dari narapidana. Suasana penuh keakraban, persaudaraan, dan sukacita dengan "payawau pakallaka" oleh kaum pria dan wanita. Media dalam ritual ini adalah tuturan-tuturan lisan yang diungkapkan dalam bentuk tanya jawab antara tetua adat yang menjawab dengan tetua adat yang bertanya. Tuturan ini diawali dengan kata "malla" yang "baiklah" dan diakhiri dengan kata "peina" artinya "bagaimana".

Dalam tuturan lisan (B2I) tersebut, ditunjukkan dengan sangat jelas identitas atau jati diri masyarakat Wewewa berkaitan dengan pertobatan seorang narapidana. Narapidana sebagai "anak yang hilang" mengakui segala perbuatannya dan mau kembali kepada ibu dan bapa yang melahirkan nyata dalam tuturan saya masuk penjara karena saya telah membunuh orang. Karena waktu hukuman telah selesai, saya mau kembali pulang ke rumah, kembali kepada ibu dan bapak. Tuturan "saya mau kembali pulang ke rumah, kembali kepada ibu dan bapak", sejatinya adalah bentuk kearifan lokal tidak berwujud (intangible) berupa tekad dan cita-cita yang menunjuk pada pertobatan atau rekonsiliasi yaitu kembali kepada jalan yang baik dan benar. Semangat untuk kembali kepada jalan yang benar sungguh berakar pada masyarakat Wewewa, lewat ungkapan mau kembali pulang kepada ibu dan bapak. Hal ini senada dengan Hultgren (2000: 78) yang memaknai pertobatan seorang anak yang hilang dalam kesadarannya maka ia pun bertobat.

Keberanian anak yang hilang menurut Hultgren (2000) pasti didasari oleh kepercayaan anak yang hilang bahwa Sang Bapa maha pengampun, karena begitu banyak kesalahannya. Di sinilah makna pertobatan ditekankan. Di tengah mengalami keterpurukan, anak yang hilang mulai menyadari cinta yang sebenarnya, entah kaya, miskin, gembira, sedih, berharga atau pun tak berharga, ia tetaplah anak dari bapa yang melahirkan. Martabat keputeraan dan kasih Bapa tetap ada baginya walaupun ia telah kehilangan hal itu. Saat ia ingin diperlakukan seperti hamba sebenarnya ia adalah putra yang juga dikasihi. Hal inilah yang membuat dia bertobat dan layak hidup menjadi putra.

Kembalinya narapidana sebagai "anak yang hilang" ke kampung halamannya karena kampung adalah landasan kehidupan manusia. Dalam pelana kampung inilah para leluhur berjanji untuk menanam keselasarasan, keutuhan, dan keharmonisan bagi semua ciptaan di alam raya (Neonbasu, 2016: 75). Artinya, janji tersebut merupakan spirit perjuangan para leluhur untuk selalu menjaga keharmonisan dalam masyarakat Wewewa. Pertobatan "anak yang hilang" dalam masyarakat Wewewa dilihat sebagai jati diri yang melekat dalam hidup mereka, karena ibu dan bapa yang melahirkan tidak pernah menolak kembalinya anak yang hilang. Kesadaran narapidana akan kebermaknaan hidup sebagai "anak yang hilang" untuk kembali kepada jalan yang benar adalah semangat tobat yang dimiliki oleh setiap orang. Bastaman (2007) dalam Arista (2017: 605) menegaskan bahwa kebermaknaan hidup adalah penghayatan individu terhadap hal-hal yang dianggap penting, dirasakan berharga, diyakini kebenarannya dan memberi nilai khusus bagi seseorang, sehingga dijadikan tujuan dalam kehidupan (the purpose in life). Artinya, penghayatan hidup bermakna merupakan gerbang ke arah kepuasan dan kebahagiaan hidup, apabila seseorang berhasil mencapai ataupun mendapatkan 
makna hidupnya maka kehidupan terasa penting dan berharga, dengan demikian akan menimbulkan penghayatan bagi dirinya sendiri.

\section{Kebersamaan}

Dalam Kamus Besar Bahasa Indonesia (KBBI, 2008), kata kebersamaan merupakan kata turunan dari kata dasar sama yang berarti hal bersama. Sementara kata dasar sama berarti (1) serupa (halnya, keadaannya, dan sebagainya); tidak berbeda; tidak berlainan; (2) berbarengan; bertepatan; dan (3) sepadan; seimbang; sebanding; setara.

Salaki (2014: 50) memaknai kebersamaan yang ditunjukkan dengan hidup bersama dan maju bersama, merasa senasib dan sepenanggungan. Kebersamaan adalah kata yang selalu kita inginkan keberadaannya untuk menjaga hubungan harmonis antara kita dengan lingkungan sekitar. Kebersamaan adalah suatu keadaan di mana semua anggota suatu kelompok mempunyai rasa saling memiliki, saling bekerja sama serta saling mendukung dalam setiap keadaan sehingga dapat menciptakan sebuah kelompok yang solid. Demikian juga kebersamaan sebagai anggota gereja dalam masyarakat Wewewa. Informan dalam (W/JDMW/6) mengatakan bahwa kebersamaan antara pemimpin gereja dengan umatnya sungguh berakar dalam kehidupan mereka. Dialog dan saling meneguhkan satu sama lain terjadi dalam kebersamaan itu. Jati diri kebersamaan dalam masyarakat Wewewa dapat dilihat dalam tuturan lisan $O k a$ di bawah ini.

"Malla! Inda wukku kina baku kadi wu koko, inda wuku kina baku zosiwu ate. Angu nggarai lunggu, tukku nawe bina morra, angu nggarai lunggu bera nawe ndOka kaka lunggu, niaka ku kadi wu koko, niaka ku zosiwu ate. Indaki, inna wangga a walina nataru mandatti ba lummu ko. Ama wangga a walina kalena yaro yari balummu ko, ku pandema nggu limma, pandema nggu kara. Ndappa kinda kiu koko, ndappa labu kiu ate. Nggai ka maweima ringi loko, nggai kama weimagabbo mara. Ba apa ko pa ame dengani inna, pa ami dengani ama. Ka enga ngge, koro wanno, gollu Oka. Tau!" "Baiklah! Karena yang datang adalah bapak dan ibu dari rumah besar, maka kami menadahkan tangan, membentangkan hati menerima kedatangan. Kami mau melihat terang dan merasakan kesejukan. Masuklah, kami bukakan pintu, kami lapangkan jalan. Tinggallah bersama kami. Jawablah!”. (C3T).

Konteks:

Tuturan tersebut diungkapkan oleh tetua adat sebagai tuan rumah yang bertanya ketika menyambut uskup sebagai pemimpin gereja setempat yang berkunjung di sebuah paroki. Ritual ini diadakan di pintu gerbang pada pagi hari. Mitra tutur dalam tuturan ini adalah tetua adat yang menjawab mewakili uskup dan rombongan. Tujuan dari ritual ini adalah menerima kehadiran uskup sebagai pemimpin gereja di tengah umat dengan tangan dan hati terbuka. Suasana dalam ritual ini penuh sukacita dengan "payawau pakalakka" (seruan kegembiraan yang dilakukan oleh kaum pria maupun wanita). Media yang digunakan dalam ritual ini adalah tuturan-tuturan lisan dalam bentuk tanyajawab antara tetua adat yang bertanya dengan tetua adat yang menjawab. Ritual ini diawali dengan seruan "malla" yang berarti "baiklah" dan diakhiri dengan kata "tau" yang berarti "jawablah".

Dalam tuturan lisan (C3T) tersebut, ditunjukkan dengan sangat jelas identitas atau jati diri masyarakat Wewewa berkaitan dengan kebersamaan yaitu kami menadahkan tangan, membentangkan hati menerima kedatangan. Kami mau melihat terang dan merasakan kesejukan. Dalam keadaan bersama, tentu ada rasa kebersamaan. Tuturan "kami menadakan tangan, membentangkan hati menerima kedatangan" sesungguhnya adalah bentuk kearifan lokal yang tidak berwujud (intangible) berupa tekad atau citacita yang menunjuk kepada entitas kebersamaan dalam persekutuan antara uskup sebagai pemimpin gereja dengan umatnya. Namun rasa kebersamaan itu dapat muncul dan diawali dari keadaan bersama. Rasa kebersamaan tersebut akan muncul ketika orang bersama-sama dalam suatu kondisi, dalam kegiatan yang sama, menanggung beban yang sama, merasa sehati dan sejiwa. Hal ini senada dengan Mardiatmadja (2017: 30) yang mengutip dari Konstitusi Pastoral (GS a.1) Dokumen Konsili Vatikan II, menegaskan bahwa kegembiraan dan harapan umat manusia juga menjadi kegembiraan dan harapan gereja. Artinya dalam kebersamaan, 
sumbangsih utama segenap anggota gereja adalah untuk kebaikan bersama. Setiap anggota gereja dapat bersatu dan hidup senasib sepenanggungan untuk kebaikan bersama. Jati diri kebersamaan ini ternyata ada dan hidup dalam masyarakat Wewewa. Masyarakat Wewewa menjunjung tinggi semangat kebersamaan ini seperti yang disampaikan oleh informan dalam (W/JDMW/6) bahwa antara pemimpin gereja dan umatnya dalam melaksanakan program, tidak ada yang berjalan sendiri-sendiri tetapi dalam nuansa kebersamaan.

\section{Pengucapan Syukur}

Dalam Kamus Besar Bahasa Indonesia (2008), kata syukur berarti (1) rasa terima kasih kepada Allah (2) untunglah/pernyataan lega, senang, dan sebagainya. Park\& Seligman dalam Haryanto (2016: 110) mengemukakan bahwasyukur digambarkan dengan kondisi individu yang sadar dan berterimakasih atas segala hal baik yang terjadi. Individu dalam hal ini dituntut untuk mengekspresikan dan mengungkapkanrasa terimakasih.Syukurmerupakan bentuk emosi yang menyenangkan, didahului dengan terbentuknya suatu persepsi bahwa dirinya mendapatkan suatu manfaat dari pemberian orang lain. Hal ini senada dengan Graham \&Fincham dalam Haryanto (2016) yang mengatakan bahwa syukur diungkapkan sebagai bentuk perasaan yang dialami oleh individu ketika menerima suatu kebaikan atau keuntungan dari seseorang. Sementara McCullough \& Tsang dalam Haryanto (2016) menjelaskan konsep syukur sebagai bentuk perasaan takjub, berterimakasih, dan menghargai atas manfaat yang diperolehnya. Perasaan tersebut bisa diarahkan pada orang lain maupun pada diri sendiri.

Jati diri pengucapan syukur, seperti yang dikatakan oleh informan, sejatinya berangkat dari masyarakat yang hidup dalam budaya agraris, sebagaimana dalam masyarakat Wewewa yang dianugerahi tanah subur, sehingga manusia hidup dari apa yang ditanam di alam (W/JDMW/4). Rasa syukur atas anugerah alam itu, yang oleh masyarakat Wewewa dipercaya sebagai pemberian sang pencipta sebagai pemelihara alam raya itu, patut disyukuri. Syukur adalah bentuk rasa berterimakasih individu terhadap segala sesuatu yang terjadi dalam hidupnya, baik kejadian maupun menerima sesuatu dari pihak lain. Termasuk juga di dalamnya respon kegembiraan dan kecenderungan untuk melihat kehidupannya sebagai anugerah.
Watkins, Woodward, Stone dan Kolts (2003) dalam Sativa dan Helmi (2016: 3) mengatakan bahwa syukur memiliki hubungan dengan berbagai aspek dan komponen terhadap kebahagiaan. Individu yang memiliki pola pikir untuk terus bersyukur adalah individu yang bahagia. Pada individu yang memiliki tingkat syukur yang tinggi, memiliki kebahagiaan yang tinggi, karena ada kecenderungan untuk lebih puas dan optimis jika dibandingkan dengan individu yang tidak bersyukur. Sebaliknya kecemasan dan depresi diketahui lebih tinggi pada individu yang tidak bersyukur (Mccullough (2006), dalam Sativa (2016: 3). Selain itu syukur memunculkan emosi positif, kognitif yang positif, dan memori yang positif pada individu, sehingga memunculkan evaluasi yang positif ketika individu mengevaluasi kehidupannya.

Perilaku syukur merupakan salah satu bentuk kecerdasan spiritual (spiritual quotient) yang bisa memberikan energi dahsyat bagi manusia dalam memperoleh ketenangan dan kedamaian. Energi yang terdapat dalam zona syukur bisa membuat manusia tegar dalam menghadapi semua ketentuan Tuhan. Seseorang yang menyadari dan memanfaatkan pola kecerdasan ini, akan mampu menjadikan kegagalan sebagai modal meraih kesuksesan, musibah sebagai ujian, jubah kepangkatan menjadi kain kafan, kecemasan menjadi ketenangan, marah menjadi senyuman, dan kekayaan menjadi ladang memperbanyak amal (Taufik, 2017: 176-177).

Dimensi psikologis menjadi bagian penting dari perilaku syukur yang merupakan salah satu dimensi yang bisa memengaruhi motivasi seseorang untuk membiasakan diri bersyukur kepada Tuhan. Dimensi psikologis yang tampak dalam perilaku syukur adalah menyangkut mental manusia dalam menggerakkan hatinya untuk berbagi kepada sesama setelah memperoleh kenikmatan dari Tuhan (Carr, 2016: 10). Mental menjadi landasan bagi pemikiran manusia untuk memenuhi kebutuhan yang belum terjangkau sehingga memengaruhi setiap keputusan dan langkah yang dapat diambil. Perilaku syukur merupakan persoalan mental yang bisa dibina sejak seseorang masih dalam pengawasan orangtua.

Syukur adalah sarana untuk memanfaatkan dan memelihara karunianya. Hati yang bersyukur dapat memperkuat dan memantapkan kebaikan yang sudah dilakukan serta akan menghasilkan kebaikan yang belum ada. Orang awam hanya 
bersyukur bila memperoleh rezeki material. Sementara orang-orang yang memperoleh pencerahan batin selalu bersyukur, baik ketika memperoleh berkat atau pun tidak. Jati diri pengucapan syukur sesungguhnya melekat pada masyarakat Wewewa, dapat ditelusuri dalam tuturan $\mathrm{Oka}$ berikut ini.

"Malla! Bakku ana pa palewa nggu, bakku alli pa patuka nggu. Kako ndari tana, kako batu ruta balunggu nggu. Bau kole ba dongge a pakambou lele limma na, bau kole ba dongge a patollu manu wai na. Ndakku pasapa kinggu kukku na, ndakku patetti kinggu ngora na. Ku pandema nggu tete, ku pamangga nggu outa. Ngindiya wulli pare, wulli watara. Tau!"

"Baiklah! Sama saudara yang berjuang dan bekerja keras di kebun. Kami bukakan pintu, kami lapangkan jalan. Masuklah, bawalah bulir padi dan jagung ke rumah besar. Jawablah!"'. (A3T).

\section{Konteks:}

Tuturan tersebut diungkapkan oleh tetua adat sebagai tuan rumah yang bertanya ketika menyambut masyarakat yang membawa hasil panen. Ritual ini diadakan di pintu gerbang pada sore hari. Mitra tutur dalam ritual ini adalah tetua adat yang menjawab mewakili masyarakat yang membawa hasil panen. Tujuan dari ritual ini adalah menerima hasil panenan untuk dibawa masuk ke rumah besar. Ritual ini dilaksanakan dalam suasana gembira dengan "payawau pakalakka" (seruan kegembiraan yang dilakukan oleh kaum pria maupun wanita). Media yang digunakan dalam ritual ini adalah tuturantuturan lisan dalam bentuk tanyajawab antara tetua adat yang bertanya dengan tetua adat yang menjawab. Ritual ini diawali dengan seruan 'malla" yang berarti "baiklah" dan diakhiri dengan kata "tau" yang berarti "jawablah".

Dalam tuturan lisan Oka (A3T) tersebut, ditunjukkan dengan sangat jelas identitas atau jati diri masyarakat Wewewa berkaitan dengan pengucapan syukur yaitu kami bukakan pintu, kami lapangkan jalan. Masuklah, bawalah bulir padi dan jagung ke rumah besar. Tuturan "kami bukakan pintu, kami lapangkan jalan, masuklah, bawalah bulir padi dan jagung ke rumah besar", sesungguhnya adalah bentuk kearifan lokal yang tidak berwujud (intangible) berupa kegembiraan dan sukacita yang menunjuk pada entitas syukur atas hasil panen yang berlimpah. Masyarakat Wewewa sadar, bahwa mereka telah bekerja keras dan mereka telah memetik hasil. Membawa masuk hasil panen berupa bulir padi dan jagung adalah bentuk ucapan syukur masyarakat Wewewa atas hasil yang mereka terima. Hal ini senada dengan yang dikatakan Fadhala (2013) dalam Taufik (2016: 182) bahwa bersyukur merupakan upaya seseorang untuk memantapkan keyakinan karunia Allah yang sangat besar di muka bumi ini. Jati diri pengucapan syukur diperoleh juga dalam makna pragmatik menerima saat menyambut rombongan yang membawa material bangunan. Hal ini tercermin dalam tuturan lisan $\mathrm{Oka}$ berikut ini.

"Malla! Angu nggarai lunggu nia ku kadi wu koko, angu nggarai lunggu nia ku zosi wu ate. Barata pawikka, timura patondo wa lunggu. Ba yemmi dona ana alli nggu, ba yemmi dona wolla riwu rawu wua tanenda tana nggu. A matallara puu punda eri wali ndari tana. A mawesara mata mboro bisa wali batu ruta. Ba hinna ko, ku wukke nggu binna, ku buwe nggu lara. Kau dukki ngge uma katonga, weli umbu weli waika. Kau katukku ni nggasu wasu, kau sero ngge ngaingo a wobola. Tama wu, ku wukke banggu binna, ku bowa banggu lara. Tau!" "Baiklah! Kami pikir siapa yang datang sehingga kami bertanya dan menyelidiki. Kami pikir yang datang adalah orang asing. Bila kamu adalah anak cucu yang tersebar dari tempat berkebun, sekarang kami bukakan pintu, lapangkan jalan, agar masuk ke dalam kampung dengan aman tanpa halangan. Supaya tiba di rumah ibu dan bapa dan bale-bale bekas rumah kakek dan nenek leluhurmu, agar kamu membangun kembali rumah yang rusak. Jawablah!" (E3T).

\section{Konteks:}

Tuturan tersebut diungkapkan oleh tetua adat sebagai tuan rumah yang bertanya ketika menyambut masyarakat yang membawa material bangunan dari hutan. Ritual ini dilaksanakan di pintu gerbang kampung pada sore hari. Mitra tutur dalam ritual ini adalah tetua adat yang menjawab 
mewakili masyarakat yang membawa material bangunan. Tujuan ritual ini untuk menerima material bangunan yang dibawa dari hutan masuk ke rumah besar. Ritual ini dilaksanakan dalam suasana gembira dengan "payawau pakalakka" (ungkapan atau seruan kegembiraan yang dilakukan oleh kaum pria maupun wanita). Media yang digunakan dalam ritual ini adalah tuturan-tuturan lisan dalam bentuk tanyajawab antara tetua adat yang bertanya dan tetua adat yang menjawab. Ritual ini diawali dengan seruan "malla' yang berarti "baiklah" dan diakhiri dengan kata "tau" yang berarti "jawablah".

Dalam tuturan lisan (E3T) tersebut, ditunjukkan dengan sangat jelas identitas atau jati diri masyarakat Wewewa berkaitan dengan pengucapan syukur yaitu bukakan pintu, lapangkan jalan, agar masuk ke dalam kampung dengan aman tanpa halangan. Supaya tiba di rumah ibu dan bapa dan bale-bale bekas rumah kakek dan nenek leluhurmu, agar kamu membangun kembali rumah yang rusak. Tuturan "bukakan pintu, lapangkan jalan agar masuk ke dalam kampung dengan aman tanpa halangan", sejatinya adalah bentuk kearifan lokal yang tidak berwujud (intangible) berupa kegembiraan dan sukacita yang menunjuk kepada entitas yakni syukur karena telah memperoleh material bangunan. Masyarakat Wewewa sadar, bahwa mereka telah bekerja keras dan mereka telah berhasil membawa material bangunan dari hutan. Membawa masuk material bangunan dari hutan berupa kayu, alang dan tali adalah bentuk ucapan syukur masyarakat Wewewa atas hasil yang mereka peroleh. Hal ini senada dengan Fadhala (2013) dalam Taufik (2016: 182) yang mengatakan bahwa pengucapan bersyukur mencerminkan bagaimana manusia mengakui dan menyadari sepenuhnya segala rahmat yang diperoleh berasal dari Allah dan tiada seorang pun selain Allah yang dapat memberikan rahmat yang tidak terbatas ini.

\section{Kekeluargaan}

Kekeluargaan merupakan aspek penting yang banyak diterapkan di berbagai tempat. Dalam Kamus Besar Bahasa Indonesia (2008), kata kekeluargaan adalah turunan dari kata keluarga yang berarti (1) ibu dan bapak beserta anak-anak, seisi rumah (2) orang seisi rumah yang menjadi tanggungan, batih (3) kaum, sanak saudara, kaum kerabat (4) satuan kekerabatan yang sangat mendasar dalam masyarakat. Kekeluargaan berkaitan dengan yang bersifat atau berciri keluarga. Soewardi (1989) dalam Ruslina (2012: 2) mengatakan bahwasemangat kekeluargaan merupakan corak budaya bangsa Indonesia. Oleh karena itu sikap, pemikiran, perilaku dan tanggungjawab seorang warga bangsa kepada kolektivitasnya senantiasa berada di atas kepentingan individu.

Kekeluargaan merupakan satuan mendasar dari kekerabatan. Rasa kekeluargaan tidak hanya ada pada kelompok dengan hubungan darah. Apabila suatu perkumpulan masyarakat memiliki rasa solidaritas yang cukup tinggi dan terus dipupuk, maka muncul istilah rasa kekeluargaan. Hal ini sejalan dengan informan dalam (W/JDMW/7) yang mengatakan bahwa dalam satu keluarga, setiap orang saling memahami dan mengenal anggota keluarganya, merasa terikat dengannya, sehingga hal apapun yang terjadi dengan salah satu anggotanya berarti mengusik satu kesatuan keluarga itu.

Berdasarkan pengertian dari kekeluargaan tersebut, semangat kekeluargan sesungguhnya merupakan jati diri yang melekat pada masyarakat Wewewa. Neonbasu (2016: 69) mengatakan bahwa semangat kekeluargaan masyarakat Wewewa tercermin dalam semangat kerja sama dan gotong royong yaitu Ghorona pu'u, kadona lawi yang berarti "bersama mengangkat pangkal yang berat, bersatu mengangkat ujung yang ringan. Masyarakat Wewewa senantiasa bersatu mengerjakan yang berat maupun yang ringan. Jati diri kekeluargaan diperoleh dalam makna pragmatik menerima saat menyambut narapidana dan rombongan memasuki kampung dan rumah besar. Hal ini tercermin dalam tuturan lisan $\mathrm{Oka}$ berikut ini.

"Malla! Ne bahinawe wukke ngga binna, buwe ngga lara ngge. Kaku dukki ngge uma katonga kaku ngaa ko ngaa derra, kaku enu ko wee derra, nggai $k a k u$ weimaringi loko ki baku tomana kenga ana wosa, nggai kaku we'e ma nggabo maraki baku duki ndi susu waikarere. Tau!"

"Baiklah! Selamat datang kembali di rumahmu. Kami bukakan pintu, kami lapangkan jalan. Masuklah, duduklah, makanlah dan minumlah. Rasakanlah keindahan dan kesejukan hidup bersama dalam damai sebagai saudara dalam satu keluarga. Jawablah". (B3T). 
Konteks:

Tuturan tersebut diungkapkan oleh tetua adat sebagai tuan rumah yang bertanya ketika menyambut narapidana yang keluar dari penjara kembali ke kampungnya bersama rombongan. Ritual ini diadakan di pintu gerbang pada pagi hari. Mitra tutur dalam tuturan ini adalah tetua adat yang menjawab mewakili narapidana dan rombongan. Tujuan dari ritual ini adalah menerima kembali narapidana di tengah keluarga sebagai anak dan saudara serumah. Ritual ini terjadi dalam suasana haru, empati, dan gembira dengan "payawau pakalakka" (seruan kegembiraan yang dilakukan oleh kaum pria maupun wanita). Media yang digunakan dalam tuturan ini adalah tuturan-tuturan lisan dalam bentuk tanyajawab antara tetua adat yang bertanya dan tetua adat yang menjawab. Ritual ini diawali dengan seruan "malla" yang berarti "baiklah" dan diakhiri dengan kata "tau" yang berarti "jawablah".

Dalam tuturan lisan (B3T) tersebut, ditunjukkan dengan sangat jelas identitas atau jati diri masyarakat Wewewa berkaitan dengan semangat kekeluargaan yaitu kami bukakan pintu, kami lapangkan jalan. Masuklah, duduklah, makanlah dan minumlah. Rasakanlah keindahan dan kesejukan hidup bersama dalam damai sebagai saudara dalam satu keluarga. Tuturan "masuklah, duduklah, makanlah dan minumlah. Rasakanlah keindahan dan kesejukan hidup bersama dalam damai sebagai saudara dalam satu keluarga", sesungguhnya adalah bentuk kearifan lokal yang tidak berwujud (intangible) berupa petuah, nasehat kepada anak-anak, keluarga dan segenap warga masyarakat yang menunjuk kepada entitas kekeluargaan. Masyarakat Wewewa sadar bahwa semangat kekeluargaan harus tetap dipupuk dengan tetap menghormati hak dan martabat anggota keluarga walaupun perbuatan dan tindakannya jahat. Hal ini senada dengan Kaelan (1993) dalam Kirom (2011: 107) yang mengatakan bahwa dalam dasar negara Pancasila khususnya sila kelima, menekankan perbuatan-perbuatan yang luhur yang mencerminkan sikap dan suasana kekeluargaan dan kegotong-royongan, bersikap adil, menghormati hak-hak orang lain, suka memberi pertolongan kepada orang lain, tidak melakukan perbuatan yang merugikan kepentingan umum, bersama-sama berusaha mewujudkan kemajuan yang merata dan berkeadilan sosial. Jati diri kekeluargaan diperoleh juga dalam makna pragmatik menerima saat menyambut bupati sebagai pemimpin wilayah setempat. Hal ini termanifestasi dalam tuturan lisan Oka berikut ini.

"Malla! Noto angu barata pawikka lunggu, noto angu timura patondo lunggu. Angu kedu mai pawunu lunggu, angu wawi mai pangasa lunggu. Mai rara nangga mata, mai ngenge nangga ulle lunggu. Indaki, inna wangga a mai totOka paredda a neena ndari tana, ama wangga a mai nggelOka pangadu a neena batu ruta. Tau!"'

"Baiklah! Kami pikir yang datang adalah orang lain dari luar. Orang yang mengganggu dan merusak. Tetapi karena yang datang adalah ibu dan bapa yang berkunjung, yang mau melihat kami bekerja, kami bukakan pintu, kami lapangkan jalan. Masuklah dan berbicaralah kepada kami maksud dan tujuan kedatangan ibu dan bapa. Jawablah!". (D3T).

Konteks:

Tuturan tersebut diungkapkan oleh tetua adat sebagai tuan rumah yang bertanya ketika menyambut bupati sebagai pemimpin wilayah yang berkunjung di sebuah desa. Ritual ini diadakan di pintu gerbang pagi hari. Mitra tutur dalam tuturan ini adalah tetua adat yang menjawab mewakili bupati dan rombongan. Tujuan ritual ini adalah menerima kehadiran dan kedatangan bupati sebagai pemimpin wilayah setempat. Suasana dalam ritual ini penuh sukacita dengan "payawau pakalakka" (seruan kegembiraan yang dilakukan oleh kaum pria maupun wanita). Media yang digunakan dalam ritual ini adalah tuturan-tuturan lisan dalam bentuk tanyajawab antara tetua adat yang bertanya dengan tetua adat yang menjawab. Ritual ini diawali dengan seruan "malla" yang berarti "baiklah" dan diakhiri dengan kata "tau" yang berarti "jawablah".

Dalam tuturan lisan (D3T) tersebut, ditunjukkan dengan sangat jelas identitas atau jati 
diri masyarakat Wewewa berkaitan dengan semangat kekeluargaan yaitu yang datang adalah ibu dan bapa yang berkunjung, yang mau melihat kami bekerja, kami bukakan pintu, kami lapangkan jalan. Masuklah dan berbicaralah kepada kami maksud dan tujuan kedatangan ibu dan bapa. Tuturan "yang datang adalah ibu dan bapa yang berkunjung, yang mau melihat kami bekerja", sejatinya adalah bentuk kearifan lokal tidak berwujud (intangible) berupa pengakuan sebagai ibu dan bapa yang menunjuk kepada entitas kekeluargaan. Masyarakat Wewewa sadar bahwa semangat kekeluargaan harus tetap dirawat dan dipelihara satu dengan yang lain, termasuk antara pemimpin dan rakyatnya. Hal ini senada dengan Pranarka (1985) dalam Sudaryanto (2007: 155-156) yang mengatakan bahwa ciri alam pikir kebudayaan Indonesia itu di antaranya: cita-cita persatuan hidup, keseimbangan lahir batin antara pemimpinnya dengan rakyatnya, antara rakyat yang satu dengan lain, dan segala golongan diliputi oleh semangat gotong-royong, serta semangat kekeluargaan.

\section{SIMPULAN}

Tradisi lisan $O \mathrm{Ka}$ menggambarkan jati diri masyarakat Wewewa, yakni (1) penghormatan kepada leluhur; (2) penghormatan kepada pemimpin; (3) pertobatan anak yang hilang; (4) kerja keras; (5) kebersamaan; (6) syukur; dan (7) kekeluargaan. Jati diri masyarakat Wewewa tersebut senantiasa berakar dalam kehidupan masyarakat Wewewa. Penghormatan kepada leluhur adalah wujud penghormatan mereka kepada orang yang telah meninggal dunia didasarkan kecintaan dan rasa hormat kepada mereka. Ada keyakinan dan kepercayaan bahwa mereka yang telah meninggal memiliki kehidupan yang berkelanjutan serta memiliki kemampuan untuk memengaruhi keberuntungan mereka yang masih hidup di dunia. Demikian pula dengan jati diri yang lain, mengandung nilai-nilai dan norma-norma yang dapat dijadikan landasan untuk keberlangsungan hidup dalam masyarakat Wewewa. Tujuh jati diri yang diperoleh dalam kajian tradisi lisan $O k a$ ini, hendaknya menjadi karakter dan kekayaan yang harus dimiliki oleh segenap anggota masyarakat Wewewa.

Tradisi lisan Oka sejatinya merupakan salah satu kearifan lokal (local wisdom) yang terdapat pada masyarakat Wewewa Sumba Barat
Daya. Bentuk dan isi dari tradisi lisan $O \mathrm{Oka}$ tergolong dalam kearifan lokal tidak berwujud (intangible) berupa perumpamaan, petuah, nasehat, harapan, dan cita-cita yang tereksplisit dalam tuturan lisan Oka. Perumpamaan, petuah, nasehat, harapan, dan cita-cita menunjuk kepada entitas tertentu sebagai jati diri/identitas masyarakat Wewewa, misalnya penghormatan kepada leluhur, penghormatan kepada pemimpin, kerja keras, pertobatan anak yang hilang, syukur, kebersamaan, dan kekeluargaan.

\section{Daftar Pustaka}

Arista, D. 2017. "Kebermaknaan Hidup dan Religiusitas pada Mantan Narapidana Kasus Pembunuhan". dalam Jurnal Psikoborneo. Volume 5, Nomor 3. Samarinda: Universitas Mulawarman.

Asnawi, S. 1999. "Semangat Kerja dan Gaya Kepemimpinan". Jurnal Psikologi.No. 2, 86-92. Jakarta: Universitas Persada Indonesia.

Carr, D. (2016). Perspective on Gratitude: An Interdisciplinary Approach. New York: Routledge. New York: Routledge.

Choiriyati, W. 2017. "Suksesi Kepemimpinan Kraton Ngayogyakarta dalam Dualitas Struktur". Jurnal Ilmu Komunikasi, Volume 15, Nomor 1. Depok: Universitas Gunadarma.

Dairo, A.B. 2015. Kajian Semiotik Tuturan dalam Ritual Oka pada Upacara Penjemputan Anak Yesus di Gereja Stasi Santa Maria Pogo Lede Desa Watu Kawula, (Skripsi), Kupang: Universitas Nusa Cendana.

Danandjaja, James, 1997. Folklor Indonesia: IlmuGosif, Dongeng, dan Lain-lain. Jakarta: Pustaka Utama Grafiti.

Darmojuwono, S. 2011. "Peran Unsur Etnopragmatis dalam Komunikasi Masyarakat Multikultural". dalam Jurnal Linguistik Indonesia. 19-34.

Daswati. 2012. "Implementasi Peran Kepemimpinan dengan Gaya Kepemimpinan Menuju Kesuksesan Organisasi”. dalam Jurnal Academica. VOL.04, No. 01. Palu: Universitas Tadulako.

Depdikbud. (2008). Kamus Besar Bahasa Indonesia. Jakarta: PT Gramedia. 
Fazrien, A. (dkk). 2015. "Peran Pemimpin dalam Pencapaian Kinerja Pegawai". dalam Jurnal Administrasi Publik (JAP), Vol.2, No. 4, Hal. 603-607. Malang: Brawijaya.

Haryanto, C.H \& Kertamuda, E.F. 2016. "Syukur sebagai Sebuah Pemaknaan". dalam Jurnal InSight, Vol. 18, No. 2. Jakarta: Universitas Paramadina.

Haviland, William A. 1999. Antropologi, Jilid 2.Jakarta: Erlangga.

Hayon, N. 1970. "A Liturgy For The Florenese People". (Disertasi). Roma: Universitas Urbaniana.

Hidayati, D. 2016. "Memudarnya Nilai Kearifan Lokal Masyarakat dalam Pengelolaan Sumber Daya Air" dalam JurnalKependudukan Indonesia. Vol. 11, No. 1. Jakarta: Lembaga Ilmu Pengetahuan Indonesia.

Hultgren, A. 2000. The Parabels of Jesus: A Comentary. Cambridge: Wm B Erdman.

Hymes, D. 1972. "Models in Interaction of Language an Social Life" dalam Gumperz dan Hymes (eds.).

Ikhwanuddin. 2012. "Implementasi Pendidikan Karakter Kerja Keras dan Kerja Sama dalam Perkuliahan". dalam Jurnal Pendidikan Karakter. Yogyakarta: Universitas Negeri Yogyakarta.

Jebadu, A. 2009. Bukan Berhala Penghormatan kepada Leluhur. Maumere: Penerbit Ledalero.

Kartono, K. 1990. Pemimpin dan Kepemimpinan. Jakarta: Rajawali Press.

Kirom, S. 2011. "Filsafat Ilmu dan Arah Pengembangan Pancasila: Relevansinya dalam Mengatasi Persoalan Kebangsaan". dalam Jurnal Filsafat. Vol. 21, Nomor 2. Yogyakarta: Universitas Gadjah Mada.

Made, I.N. 2011. "Wacana Ritual Melong Pare Bulu Komunitas Petani adat Bayan Lombok Utara: Kajian Etnopragmatik". (Disertasi), Denpasar: Universitas Udayana.

Mahsun. 2005. Metode Penulisan Bahasa: Tahapan Strategi, Metode, dan Tekniknya. Jakarta: Rajawali Press.

Mardiatmadja, B.S. 2017. Bersatu Padu. Yogyakarta: Penerbit Kanisius.

Mubah, S. 2011. "Strategi Meningkatkan Daya Tahan Budaya Lokal dalam Menghadapi
Arus Globalisasi”. Jurnal. Volume 24, Nomor 4. Surabaya: Universitas Airlangga.

Mulyani. 2016. "Model Kepemimpinan Etnis Tionghoa di Jawa Barat (Survei pada Perhimpunan Fuqing di Jawa Barat)". dalam Jurnal Manajemen. Volume XX, No. 03. Bandung: Universitas Katolik Parahiyangan.

Munthe A. 1996. Kabar Baik dalam Perumpamaan. Jakarta: BPK Gunung Mulia.

Neonbasu, G. 2016. Akar Kehidupan Masyarakat Sumba dalam Cita Rasa Marapu. Jakarta: LAPOPP PRESS.

Putra Manuaba, 1999. Budaya Daerah dan Jati Diri Bangsa:Pemberdayaan Cerita Rakyat dalam Memasuki Otonomi Daerah dan Globalisasi. Putera Manuaba, "Budaya Daerah dan Jati Diri Bangsa: Pemberdayaan Cerita Rakyat dalam Memasuki Otonomi Daerah dan Globalisasi,"Masyarakat, Kebudayaan dan Politik, Th XII, No 4, 57-66.

Rahardi, R.K. 2006. Dimensi-dimensi Kebahasaan: Aneka Masalah Bahasa Indonesia Terkini. Jakarta: Penerbit Erlangga.

Rahardi, R. K. 2009. Sosiopragmatik: Kajian Imperatif dalam Wadah Konteks Sosiokultural dan Konteks Situasionalnya. Jakarta: Penerbit Erlangga.

Ruslina, E. 2012. "Makna Pasal 33 UndangUndang Dasar 1945 dalam Pembangunan Hukum Ekonomi Indonesia". dalam Jurnal Konstitusi, Volume 9, Nomor 1. Bandung: Universitas Pasundan.

Salaki, J.R. 2014. "Membangun Karakter Generasi Muda Melalui Budaya Mapalus Suku Minahasa". dalam Jurnal Studi Sosial, Th. 6, No. 1. Manado: Universitas Negeri Manado.

Sativa, R.A \& Helmi, A.F. 2016. "Syukur dan Harga Diri dengan Kebahagiaan Remaja". dalam Jurnal Wacana. Yogyakarta: Fakultas Psikologi Universitas Gadjah Mada.

Song, L. 2010. The Role of Context in Discourse Analysis.Journal of Language Teaching and Research, Vol. 1, No. 6.

Spradley, J. P. 2006. Metode Etnografi. Diterjemahkan oleh Misbah Zulfah Elizabeth. Yogyakarta: Tiara Wacana.

Sudaryanto. 2007. "Kekeluargaan sebagai Kunci Pemahaman Pancasila". dalam Jurnal 
Filsafat. Vol.17, Nomor 2. Yogyakarta: Universitas Gadjah Mada.

Sudaryanto. 2015. Metode dan Aneka Teknik Analisis Bahasa, Yogyakarta: Sanata Dharma University Press.

Syamsuddin, M.M. 2010. "Pendekatan Fenomenologis dalam Studi Perbandingan Etos Kerja Manusia Bugis-Makassar dan Bangsa Jepang”. dalam Jurnal Filsafat. Vol. 20, Nomor 2. Yoyakarta: Universitas Gadjah Mada.

Taufik, A. 2017. "Kekuatan Terapi Syukur dalam MembentukPribadi yangAltruis: Perspektif Psikologi Qur'ani dan Psikologi Positif'. dalam Jurnal Studia Insania. Vol. 5, No. 2. Madura: INSTIKA.

Ujan, B.B. 2012. Mati dan Bangkit Lagi. Maumere: Penerbit Ledalero.

William A.H. 1999. Antropologi, Jilid 2. Jakarta: Erlangga. 